\title{
Lynch syndrome: History and current status
}

\author{
Henry T. Lynch and Jane F. Lynch \\ Department of Preventive Medicine, Creighton University School of Medicine, 2500 California Plaza, Omaha NE \\ 68178, USA
}

\section{Introduction}

The annual worldwide incidence of colorectal cancer (CRC) is 944,717 with a mortality of 492,411 [1]. Approximately $5 \%$ to $10 \%$ of this total CRC burden is due to primary Mendelian inheritance factors, making hereditary CRC a major public health problem throughout the world. These estimates of the hereditary burden of CRC may be conservative when considering the existence of low-penetrant genes such as the Ashkenazi I1307K mutation [2], the recently described autosomal recessive form of familial adenomatous polyposis (FAP)-like families due to the MYH mutation [3, $4]$, and the hereditary breast and colon cancer (HBCC) syndrome $[5,6]$.

Understanding the role of genetics in the etiology of $\mathrm{CRC}$ has increased rapidly during the past decade, due to the prodigious advances in molecular genetics [7]. Indeed, this information has evolved so rapidly that it has outpaced the ability of physicians to keep abreast of these fast-breaking events.

\section{Spectrum of hereditary forms of CRC}

Figure 1 depicts the relative occurrence rates of sporadic, familial, or hereditary classifications of CRC. These estimates of the familial and hereditary categories of CRC risk are probably highly conservative, given the fact that those extracolonic cancers that are integral lesions to specific hereditary CRC syndromes are often not given due consideration when evaluating pedigrees and thereby calculating estimates of the hereditary burden of CRC. The very terms "sporadic," "familial," and "hereditary" have limited meaning. For example, "sporadic" CRC (a single case of CRC) and "familial" CRC (two or more first-degree relatives with CRC) are relatively crude terms. Specifically, they do not take into consideration factors that may obfuscate, and thereby underestimate, the true incidence rate of the genetic susceptibility to CRC. These factors include the presence of cancer of other organ sites, lowpenetrant mutations, possible autosomal recessive inheritance, the general lack of genetic informativeness which may occur in a small family, adoption, false paternity, outright denial, and/or the lack of cooperation of family members and even their physicians.

\section{Proximal vs. distal hereditary CRC}

Hereditary CRC-prone syndromes can be divided into those with proximal predilection in the colon and those with distal predilection in the colon, based upon molecular genetic features. Specifically, tumors, “... that exhibit microsatellite instability (MIN) tend to occur in the right colon, have diploid DNA, carry characteristic mutations (transforming growth factor $\beta$ Type II receptor, $B A X$ ) and behave indolently. Hereditary non-polyposis colorectal cancer (HNPCC) [or Lynch syndrome] epitomises this route of tumour development. Conversely, tumours with chromosomal instability (CIN) tend to be left-sided, have aneuploid DNA, carry characteristic mutations (K-ras, $A P C, p .53)$ and behave aggressively. Familial adenomatous polyposis (FAP) epitomises this type of tumour." [8] Considerable embryologic, vascular, and molecular evidence has merged showing that there are two colons: a right colon and a left colon $[9,10]$.

Our purpose is to describe the history of the Lynch syndrome, which is the most common form of hereditary CRC, with conservative estimates that it accounts for about $2 \%$ to $7 \%$ of the total CRC burden [11]. 


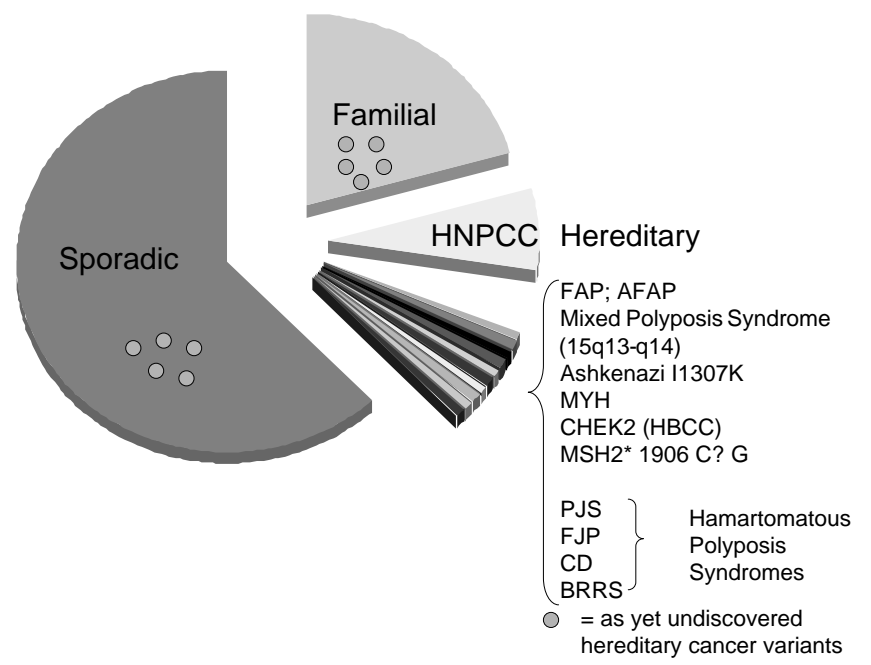

Fig. 1. Circle graph showing relative numbers of colorectal cancer cases that are considered sporadic, familial, or due to a recognized hereditary cancer syndrome. (Reprinted with permission from Lynch et al. Cancer 2004;100:53-64.) Abbreviations: HNPCC $=$ hereditary nonpolyposis colorectal cancer FAP $=$ familial adenomatous polyposis AFAP $=$ attenuated familial adenomatous polyposis PJS $=$ Peutz-Jeghers syndrome $\mathrm{FJP}=$ familial juvenile polyposis $\mathrm{CD}=$ Cowden's disease BRRS = Bannayan-Ruvalcaba-Riley syndrome.

\section{History of HNPCC (Lynch syndrome)}

In 1962, one of the authors (Henry Lynch, M.D.), who at that time was a resident in internal medicine, had a patient who was recovering from delirium tremens. When queried about his reason for excessive drinking, the patient's response was that he knew that he, like "everyone" in his family, was going to die of cancer, and that it would likely be cancer of the colon, although he realized that many other cancers had also affected the family. Shortly thereafter, he was diagnosed with adrenal cortical carcinoma. He was extremely helpful in allowing Lynch to compile his family history. With the capable help of Ann Krush, M.S.W., they began contacting the proband's relatives, many of whom were farmers residing in Missouri, Kansas, and Nebraska. The cooperation from the family members was superb. Many reported a personal history of cancer, particularly involving the colon and often with early age of onset. A significant number had had multiple primary cancers, including metachronous CRCs and, among the women, $\mathrm{CRC}$ often associated with endometrial and ovarian carcinoma.

In a review of the literature, Lynch and Krush did not find evidence for a hereditary basis for this pattern of multiple primary tumor combinations. They wondered whether they might be dealing with a "new" hereditary cancer syndrome. This kindred was labeled Family N, for "Nebraska." (The MSH2 R680X germline mutation was subsequently identified in Family $\mathrm{N}$ in the year 2000.)
These investigators spent countless weekends during the early 1960s going from hospital to hospital, particularly in agricultural communities in northwest Missouri where many of the members of Family N resided, collecting details of medical and pathology records so that the pedigree could be documented as thoroughly as possible. Most noteworthy was the fact that patients in this family who manifested colorectal carcinoma did not have multiple colonic adenomas. This was important at that time, because it was believed by many clinicians and geneticists that the only hereditary CRC disorders were those associated with evidence of multiple colonic polyps, such as FAP.

The research team was joined by Charles W. Magnuson, M.D., (now deceased), a gastroenterologist. The local hospitals provided access to their outpatient facilities and weekends were spent educating the family members, performing physical examinations, and obtaining biospecimens for future study. Additional information about their family history of cancer was accrued through detailed questionnaires for the extended family, and goals for this family study were reinforced. During these family information sessions (FISs) [12], family members often stated that, for the first time in their lives, health care professionals had expressed intense interest in the cancer occurrences in their family, and were attempting to find answers to this familial cancer puzzle. Family $\mathrm{N}$ showed a well-defined autosomal dominant mode of genetic transmission of carcinoma of the colon with early age of cancer onset, 
multiple primaries, and with the integral association of carcinoma of the endometrium and ovary.

Cancer at additional anatomic sites are now known to be part of the Lynch syndrome $[13,14]$.

In 1964, an abstract about Family $\mathrm{N}$ was submitted to the American Society of Human Genetics. It was accepted and the first scientific report of Family $\mathrm{N}$ was presented at the annual meeting of this organization. During the presentation, Marjorie W. Shaw, M.D., a geneticist at the University of Michigan School of Medicine in Ann Arbor, asked some pertinent questions, among which was whether the findings in the family could be attributed, in part, to cytoplasmic inheritance. Given the temporal setting of the early 1960s, this was one of the etiologic hypotheses regarding cancer genetics at the infrahuman level. Specifically, there was curiosity about the role of mitochondria, which especially interested Dr. Shaw because of her prior work in plant genetics. She also told the audience that she had a family from Michigan that was similar to Family N, which was subsequently labeled Family M, for "Michigan," and she invited Lynch to collaborate with her in studying this family. Lynch and Krush then made multiple additional visits to Ann Arbor to study Family $M$ with Shaw. During this timeframe, the developing research team was joined by a pathologist, Arthur L. Larsen, M.D. (now deceased), who meticulously reviewed all of the available pathology on Families $\mathrm{N}$ and M. Collectively, this work culminated in the first publication on the subject in 1966 [15].

The possibility of an oncogenic virus in interaction with a germline bmutation was also considered in the syndrome's etiology [15]. For example, given the research climate of the 1960s and the early 1970s, the cancer susceptible genotype in Families N and M and, subsequently, Family G (discussed below), was considered by the Lynch research team to be interacting with environmental carcinogens such as an oncogenic virus $[15,16]$. It was postulated that such a cancercausing virus, possibly prevalent in the general population, would prove particularly virulent to individuals with a cancer susceptible genotype. It was reasoned that if this virus was an exogenous carcinogen, it most likely would be interacting with a cancer susceptibility genotype. On a priori grounds, such an agent would most likely be ubiquitous, but would cause cancer in only a subset of highly genetically susceptible humans.

The question was then raised as to whether such an oncogenic virus, similar to the polyoma virus in mice [17], might be interacting with the cancer-prone genotype in these families. Thus it was inferred that in dominantly inherited cancer, it is not outlandish to suppose that a viral gene has become "integrated" into one of the chromosomes of the host, thereby explaining the transmission of susceptibility from one generation to the next. Furthermore, it was inferred that if viral oncogenes were ubiquitous in the environment, then everyone would have been exposed to them, but an unknown event would be required for the onset of cancer in an individual who has not acquired the oncogene. It was believed that this might have been a low-probability event, but that the phenotype (cancer) might have increased with intensified exposure to the virus [15].

\section{Family G}

The first study of a family that represented what is now known as HNPCC began in 1895, when Aldred Warthin, M.D., a renowned pathologist, learned that his seamstress was depressed because she was convinced, based on her family history, that she would one day die of cancer of the female organs or bowels. When queried about this problem, the seamstress told Warthin that it was inevitable that she would die early in life because "Everyone in my family dies of those cancers." Just as she predicted, she died at an early age of metastatic endometrial carcinoma. Warthin published a description of this family, which he called Family G, in 1913 [18]. Members of Family G had migrated to Michigan from southern Germany during the early and mid-1880s.

A. James French, M.D., chairman of pathology at the University of Michigan School of Medicine during the 1960s, learned about Lynch's study of cancer families and invited him to update the study by his predecessor Dr. Warthin. Dr. French provided Lynch with all of Warthin's meticulous pathology, clinical, and genealogical documentation of Family $\mathrm{G}$.

In addition to intensively studying the family in Michigan, Lynch and Krush also visited southern Germany and investigated those members of Family $\mathrm{G}$ who had not emigrated to the United States. The update of Family $G$ that resulted from these studies was published in 1971 [16]. In testament to the progress that has been made in the field of cancer genetics, the $M L H 2$ germline mutation responsible for cancer predisposition in Family G was subsequently identified through conversion technology in 2000 [19]. 
Table 1

Landmarks of Lynch Syndrome History

\begin{tabular}{|c|c|c|}
\hline Feature & First report & References \\
\hline Family G of Warthin (study began 1895) & 1913 & {$[18]$} \\
\hline Genetic Counseling & 1965 & {$[118,119]$} \\
\hline First report of Lynch et al. on Families N and M & 1966 & [15] \\
\hline Early age of cancer onset & 1966 & {$[15]$} \\
\hline Autosomal dominant inheritance pattern & 1966 & [15] \\
\hline Family information session (FIS) & 1966 & {$[12,15,120]$} \\
\hline Screening recommendations & 1967 & [21] \\
\hline Update of Family G & 1971 & [16] \\
\hline Proximal colon involvement & 1977 & [22] \\
\hline Beginning of study of Lynch syndrome in Uruguay & 1977 & {$[84]$} \\
\hline Recommendation of prophylactic TAH-BSO & 1978 & {$[121]$} \\
\hline Muir-Torre syndrome (as variant of Lynch syndrome) & 1980 & {$[38,122]$} \\
\hline Increased incidence of synchronous and metachronous CRC & 1982 & {$[27,28]$} \\
\hline Lynch syndrome studies begin with the Navajo & 1983 & {$[96,99,123-126]$} \\
\hline Tritiated thymidine distribution studies of rectal mucosa & 1983 & {$[23]$} \\
\hline HNPCC named "Lynch syndrome" & 1984 & {$[127]$} \\
\hline Selenium levels in Lynch syndrome studied & 1984 & {$[128]$} \\
\hline Formation of ICG-HNPCC & 1989 & {$[24,129]$} \\
\hline Lectin binding studies in FAP and HNPCC & 1990 & {$[130-132]$} \\
\hline Amsterdam I criteria & 1991 & [24] \\
\hline Accelerated carcinogenesis and interval CRC & 1992 & {$[31,36,37,43,44]$} \\
\hline First cancer susceptibility locus found on $2 p$ through linkage analysis & 1993 & {$[56]$} \\
\hline Second cancer susceptibility locus found on $3 p$ through linkage analysis & 1993 & [57] \\
\hline DNA mismatch repair genes reported & 1993 & {$[62-65]$} \\
\hline RER + (MSI) phenotype described & 1993 & {$[58]$} \\
\hline Germline mutations in the syndrome & 1993 & [62] \\
\hline MSH2 mutation identified & 1993 & [63] \\
\hline Extracolonic adenocarcinomas & 1994 & [14] \\
\hline Distinctive pathology features & 1994 & [31] \\
\hline MSH2; $M L H 1$ mutations & 1994 & {$[64,65]$} \\
\hline Creighton group's involvement in Uruguayan study & 1995 & [87] \\
\hline Historical perspective through 1995 & 1995 & [133] \\
\hline Role of DNA MMR genes in CRC tumorigenesis & 1995 & {$[134,135]$} \\
\hline Recommendations of prophylactic subtotal colectomy & 1996 & {$[108,109]$} \\
\hline Survival advantage & 1996 & {$[29,30]$} \\
\hline NIH NCI workshop on HNPCC (Bethesda Guidelines) & 1996 & [26] \\
\hline MSH6 mutation & 1997 & {$[72,136]$} \\
\hline NIH NCI update on MSI & 1997 & [137] \\
\hline Small bowel involvement & 1998 & [138] \\
\hline Founder mutation in Finland & 1998 & {$[90]$} \\
\hline Amsterdam II criteria & 1999 & [25] \\
\hline Tumor infiltrating lymphocytes and their association with MSI & 1999 & {$[32]$} \\
\hline Conversion technology & 2000 & {$[19]$} \\
\hline $\begin{array}{l}\text { A complex mutation of } M L H 1 \text { at codon } 222 \text { is associated with adolescent onset } \\
\text { of CRC (more early onset CRC families needed for study) }\end{array}$ & 2001 & [139] \\
\hline $\begin{array}{l}\text { Fluorouracil-based adjuvant chemotherapy benefits patients with stage II or stage } \\
\text { III CRC with MSS or MSI-L tumors but not those with MSI-H tumors }\end{array}$ & 2003 & {$[60]$} \\
\hline $\mathrm{H}(2) \mathrm{O}(2)$ effect improves survival in DNA MMR-deficient cell line & 2003 & {$[140]$} \\
\hline MSH2 del1- 6 founder mutation in the United States & 2003 & [100] \\
\hline
\end{tabular}

\section{Study of other "Cancer families"}

Lynch began studying other CRC-prone families and also found families in the literature whose clinical findings were suggestive of a hereditary cancer-prone syndrome [20,21]. In 1971, based on these family studies, Lynch and Krush [20] reported the criteria for the "cancer family syndrome," namely, increased inci- dence of adenocarcinoma, primarily of the colon and endometrium, increased frequency of multiple primary malignant neoplasms, early age of onset, and autosomal dominant inheritance [21]. Further study allowed Lynch et al. [22] in 1977, to add the observation that the CRCs in Lynch syndrome occur with significantly greater excess in the proximal colon with about onethird of them occurring in the cecum. Table 1 provides 
Table 2

Amsterdam I and Amsterdam II Criteria, and Bethesda Guidelines

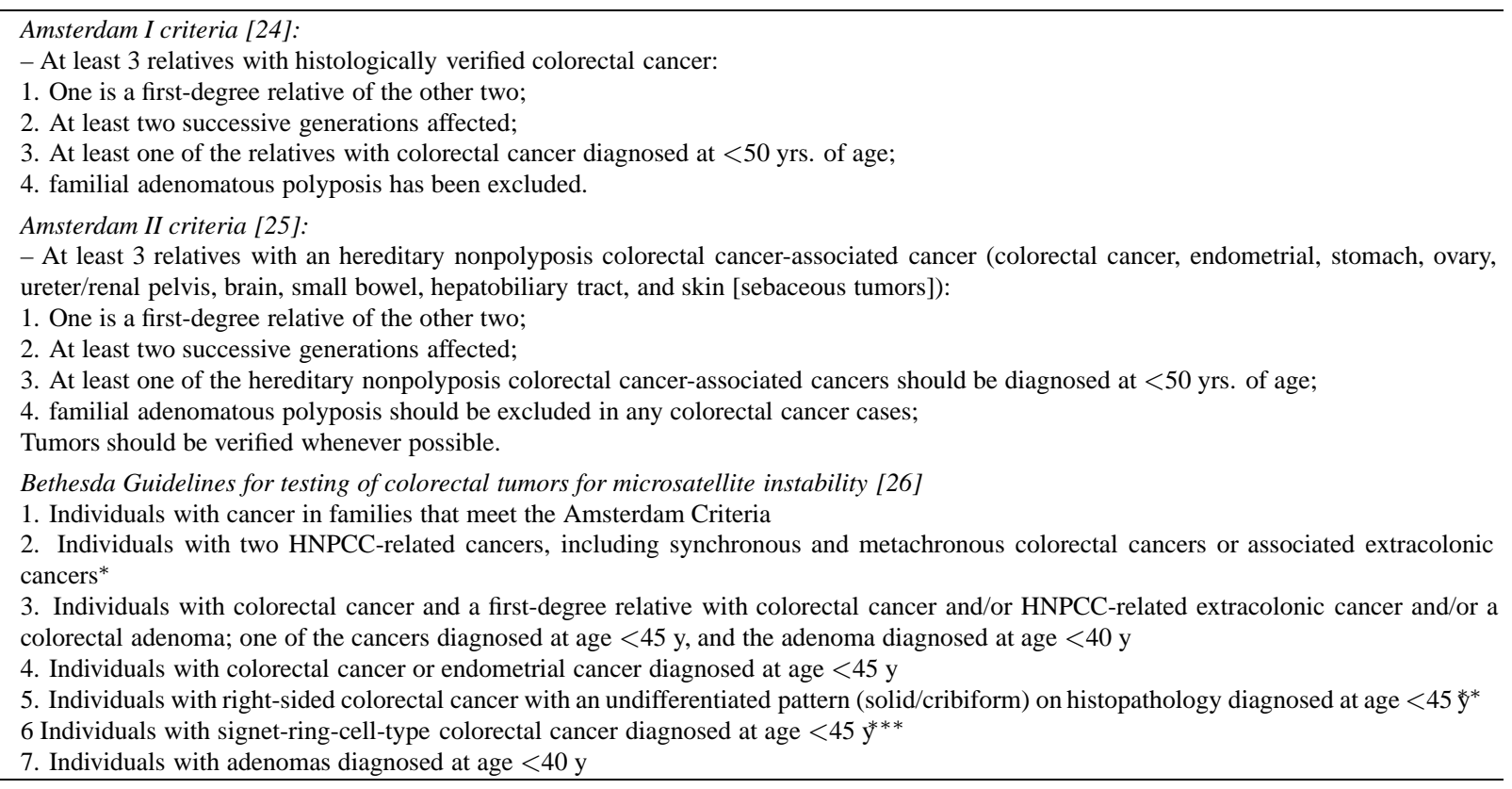

${ }^{*}$ Endometrial, ovarian, gastric, hepatobiliary, or small-bowel cancer or transitional cell carcinoma of the renal pelvis or ureter.

** Solid/cribiform defined as poorly differentiated or undifferentiated carcinoma composed of irregular, solid sheets of large eosinophilic cells and containing small gland-like spaces.

$* * *$ Composed of $>50 \%$ signet ring cells.

the chronology of the clinical, molecular, and pathology hallmarks in the Lynch syndrome.

\section{Research funding: Stretching limited funds}

Many of Lynch's research efforts in the 1960s and 1970s had been supported by very small grants and personal funds. Although the researchers had applied for significant NIH grant support, they were turned down because reviewers did not believe that genetics was the primary cause for cancer in these families. A common theme that accompanied the "pink slips" explaining the basis for rejection of the grants dealing with Lynch syndrome was the admonition to search for environmental carcinogens, particularly pesticides and herbicides, given the heavy farming background of many of the families.

The research team purchased a recreational vehicle (RV) which they had customized to contain an interview and examining room, and a small laboratory that could be used to prepare blood samples for shipment to collaborators for a variety of studies. This RV cut down significantly on travel costs for the Lynch research team. They took this vehicle to geographic areas of the country where large numbers of family members resided and would educate them as a group about the hereditary disease in their family.

For some of the FISs, particularly when visiting very large families, the hospital outpatient area or a physician's office was also utilized for educational sessions as well as for obtaining rectal mucosal research biopsy specimens for studies of tritiated thymidine labeling of colonic crypts [23]. In some cases the RV was parked at a family member's home, with relatives coming from different parts of the United States. These settings provided an excellent opportunity to get to know the family and meet with them informally. Rapport with the families was significantly enhanced during these sessions. These FISs also appeared to foster a significant group therapy psychological benefit.

Although the RV is long gone, over 150 FISs have been held for hereditary cancer families by Lynch throughout the United States and in many other areas of the world [12].

\section{Diagnosis of lynch syndrome}

Due to the lack of phenotypic stigmata that might aid in the diagnosis of the Lynch syndrome (Muir-Torre 


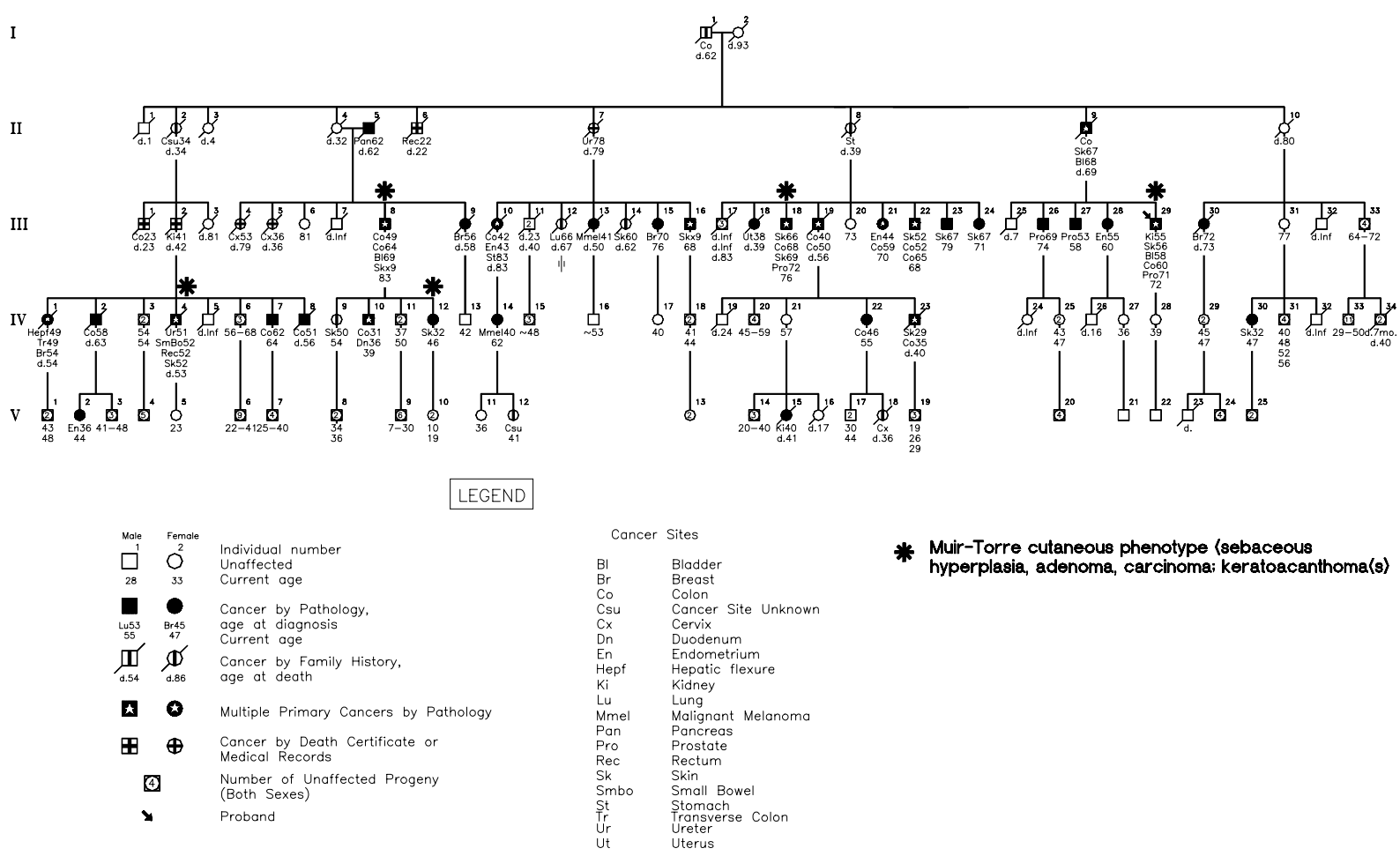

Fig. 2. Pedigree of Muir-Torre family with MSH2 mutation. (Reprinted with permission from Lynch et al. Br J Dermatol 1985;113:295-301.).

syndrome, discussed below, excepted), several sets of diagnostic guidelines have been created. These include the original Amsterdam criteria [24], the less stringent Amsterdam II criteria, 25 or the more recently described Bethesda criteria26 as seen in Table 2.

An alternative to these guidelines is "pattern recognition" which involves careful scrutiny of the phenotypic cancer features expressed in the family. This is important when dealing with such factors as small families or reduced gene penetrance of the deleterious MMR mutation. Therein, the presence of the following cardinal features should be considered for a Lynch syndrome diagnosis: (1) autosomal dominant inheritance pattern, as mentioned [15]; (2) gene penetrance for CRC of $\approx 85-90 \%$ [11]; (3) gene carriers develop CRC at an early age $(\approx 45$ years $)$ [15]; $(4)$ most $(\approx 70 \%)$ of the CRCs are proximal to the splenic flexure [22]; (5) multiple CRCs, both synchronous and metachronous, are common [27,28]; (6) the prognosis is better than that for comparably stage-matched sporadic CRC [29,30]; (7) the pathology features [31] of CRC are often distinguishable (but not pathognomic) and include poor differentiation, increased signet cells, medullary features, peritumoral lymphocytic infiltration, Crohn's-like reaction, and tumor infiltrating lymphocytes (TILs) admixed with tumor cells [32]; (8) there is an increased risk for malignancy at several extracolonic sites, particularly the endometrium, ovary, stomach, small bowel, hepatobiliary tract, pancreas, ureter, renal pelvis, and brain [13]. Breast cancer excess may be present in some HNPCC families [33]. In Warthin's Family G, gastric cancer was exceedingly common prior to 1900 , although it declined in this family in subsequent generations, paralleling its decline in the general population [16]. However, gastric cancer is still prevalent in Lynch syndrome families in Japan and Korea [34]. In addition, accelerated carcinogenesis of CRC, discussed subsequently, occurs in HNPCC [35-37].

\section{Muir-torre syndrome (MTS)}

In 1981, Lynch et al. [38] reported the first observation of the cutaneous features of MTS in the Lynch syndrome. This phenotype comprised multiple cutaneous sebaceous adenomas, sebaceous carcinomas, multiple keratoacanthomas, and multiple visceral cancers. Several papers [39-42] have elucidated the clinical and molecular genetic features of MTS. Data suggest that the identification of these MTS cutaneous features in a patient merit a detailed family history in the search for evidence of the Lynch syndrome. Indeed, patients with 
these stigmata merit germline testing, particularly for evidence of the $M L H 2$ germline mutation. An extended Lynch syndrome family with MTS that also is known to carry an MLH2 mutation is shown in Fig. 2.

\section{History of lynch syndrome pathology features}

Jass [37] elucidated the nature of the pathology of precursor lesions in HNPCC when he postulated the "aggressive adenoma" theory, i.e., adenomas in HNPCC patients form earlier but about as often as in the general population. However, once formed, these colonic adenomas progress to carcinoma more quickly and/or more often than their sporadic counterparts. This finding is consistent with accelerated carcinogenesis in HNPCC, wherein a tiny colonic adenoma may emerge into a carcinoma within two to three years, as opposed to this same process occurring in the general population, which is believed to take eight to ten years $[31,35,36,43,44]$. Strong clinical evidence in support of this phenomenon comes from a Finnish study showing a marked decrease in colon cancer incidence for HNPCC patients who have regular colonoscopic surveillance with removal of adenomas [45]. Because of accelerated carcinogenesis, proximal colonic predilection, and early age of CRC onset in the Lynch syndrome, we strongly recommend that annual full colonoscopy be initiated at age 25 (Fig. 3).

Distinctive pathology features may be present in Lynch syndrome tumors. The CRCs of Lynch syndrome tend to have a solid growth pattern that accounts for the high frequency of poorly differentiated carcinomas in a Lynch syndrome series [31]. However, these tumors do not behave as aggressively as their failure to form tubules might suggest [46]. Smyrk [47] has pointed out a resemblance to the "undifferentiated carcinoma" described by Gibbs [48] and the "medullary carcinoma" described by Jessurun [49], both of which are reported in small case series to have a better prognosis than typical colon cancer. Similar histological features characterize the $15 \%$ of sporadic colon cancers which demonstrate microsatellite instability (MSI+), a characteristic molecular change observed in tumors that lack mutation MMR activity [50]. The Mayo Clinic group has reported that this special histology, which they refer to as "solid-cribiform growth," has a positive predictive value of 53\% for MSI+ status [51].

Smyrk's second observation was that the host lymphoid response known as the "Crohn's-like reaction" is more common in HNPCC than in sporadic cancers [52].
This finding has not been consistently true in all series [31], but a similar tendency to form lymphoid aggregates around the tumor appeared to be a feature of sporadic MSI+ colon cancers as well [50].

In the general population, a Crohn's-like reaction is associated with improved prognosis [53] raising the possibility that this phenomenon accounts for the more favorable prognosis observed in HNPCC [30]. Indeed, although MSI-high (MSI-H) CRCs are often diagnosed at a significantly greater depth of tumor invasion, they appear to have a significantly lower overall pathological stage than cancers with microsatellite stability (MSS) [45,54].

Multiple observational studies have shown a survival advantage for HNPCC colon cancer patients when compared to sporadic colon cancer patients [30]. Gryfe et al. demonstrated that HNPCC patients have improved five-year survival (76\% vs. 54\%) from CRC on a stage for stage basis compared to people with sporadic tumors [54]. Similarly, the overall ten-year survival rates in affected family members is better than that seen in sporadic CRC (68\% vs. 48\%) [55].

\section{Molecular genetics}

The molecular genetic era for HNPCC began when Peltomäki et al. [56] through linkage analysis, identified a locus on chromosome $2 \mathrm{p}$ as a site for a gene predisposing to HNPCC. Shortly thereafter, a second locus believed to be etiologic for HNPCC was identified on chromosome 3p by Lindblom in Sweden [57]. At this time it was also demonstrated that the tumors occurring in HNPCC patients had a characteristic molecular change called replication error phenotype (RER), which is now called microsatellite instability (MSI) [58-61]. The subsequent recognition that MSI is the consequence of defective DNA replication error repair, or "DNA proofreading," was contributory to the discovery at the $2 p$ and $3 p$ loci of genes for HNPCC, MSH2 and $M L H 1$, which encode proteins involved in the identification and repair of DNA mismatch errors [62-65]. The DNA MMR system performs a proofreading, or "housekeeping," function. Cells lacking effective DNA MMR accumulate mutations at a very high rate [11].

The identification of germline mutations in $h M L H 1$ and $h M S H 2$ was quickly followed by the discovery that other genes that encode for members of the MMR complex are mutated in some HNPCC families, establishing significant locus heterogeneity for HNPCC. The genes 
Part A

Lynch Syndrome: Diagnosis and Management

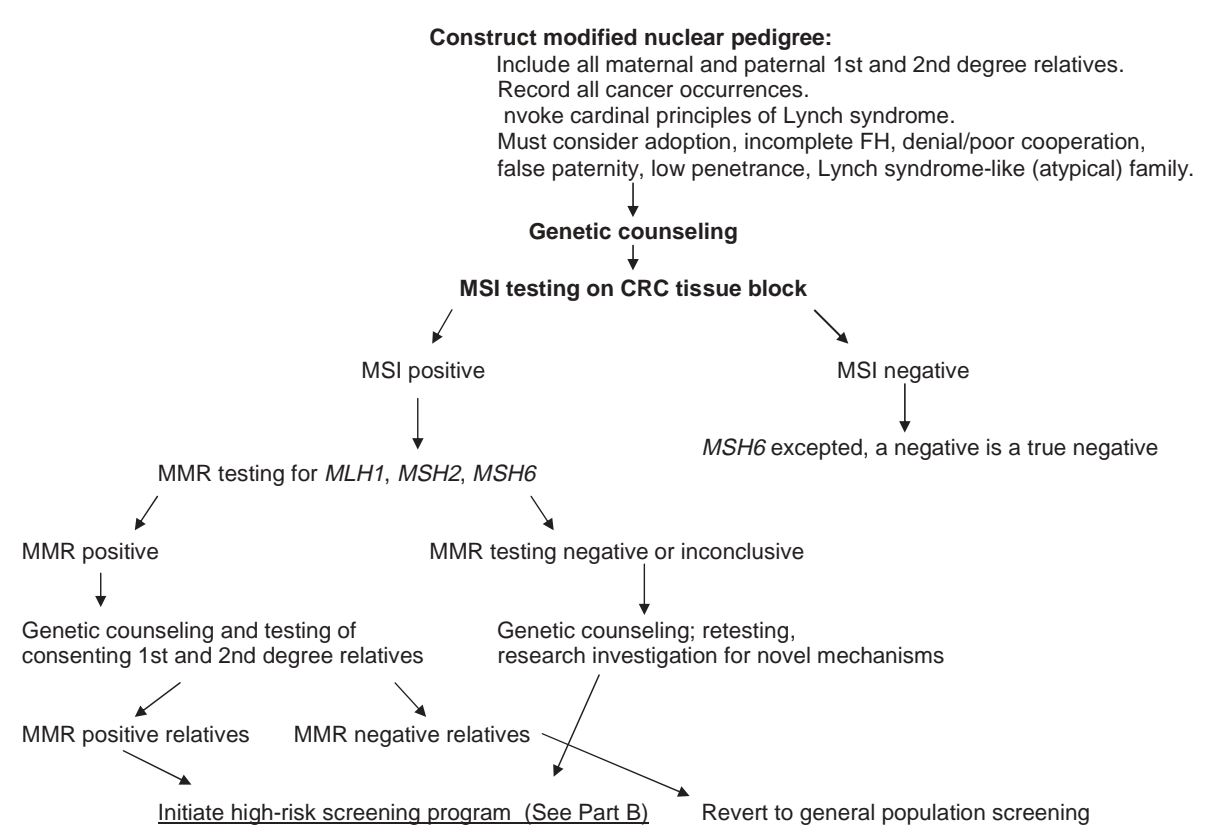

Fig. 3a. Algorithm showing proposed diagnosis and management procedures for Lynch syndrome families.

identified to date to cause HNPCC include $h M L H 1$, hMSH2, hMSH6, hPMS1, hPMS2, and hMLH3 [56,57, 62-70].

Ideally, a presumptive hereditary cancer syndrome diagnosis can be confirmed by molecular genetic testing of an affected individual in disorders where deleterious germline mutations have been identified. In the case of the Lynch syndrome, the sine qua non for its diagnosis, namely identification of mismatch repair (MMR) germline mutations, can be established in only about half of clinically diagnosed families. Specifically, Lynch syndrome, as mentioned, is associated with germline mutations in, or the malfunctioning of, post-replicative MMR genes. Two genes, MLH1 and MSH2, account for almost $90 \%$ of identified MMR mutations, while MSH6 will account for about $10 \%$. Also seen are mutations in PMS2, MLH3, and EXO1 [7173].

Why is it that only about half of classical Lynch syndrome families are shown to harbor a MMR mutation or some FAP families lack an identified APC mutation? Renkonen et al. [74] in noting that Lynch syndrome as well as FAP families may fail to show any structural change in the presently known susceptibility genes, suggest that either these genes have alterations that escape detection by conventional techniques, or other, as yet unknown, susceptibility genes are involved. These authors suggest that significant proportions of families presumed to be mutation-negative (up to $11 / 26$ families, or $42 \%$, for HNPCC; up to $4 / 16$ families, or $25 \%$, for FAP) harbor "hidden" alterations in known predisposition genes. They conclude that, “... Evidence of such changes may be obtained by expression-based methods."

These discoveries were made by a variety of talented investigators, including prominently the laboratories of Drs. Bert Vogelstein, Albert de la Chapelle, Richard Kolodner, Päivi Peltomäki, Annika Lindblom, Richard Fishel and Riccardo Fodde.

\section{A clinical-molecular genetic model}

For diagnostic purposes it is usually sufficient to consider $M L H 1$ and $M S H 2$, and test other genes, particularly MSH6, only if mutations are not found in these two. Identification of the culprit predisposing germline mutation in a Lynch syndrome family will determine who should participate in highly targeted cancer surveillance and management programs and, alternatively, those who test negative in a setting where a known mutation has been verified should then follow general population screening guidelines (see Fig. 3). 


\section{Part B}

Screening and management melded to cardinal features of Lynch Syndrome

\begin{tabular}{|c|c|}
\hline Cardinal Features of Lynch Syndrome & $\underline{\text { Screening/Management }}$ \\
\hline $\begin{array}{l}\text { Proximal colonic predilection } \\
\text { Early age of onset } \\
\text { Accelerated carcinogenesis } \\
\text { Predisposition to synchronous and } \\
\text { metachronous CRCs }\end{array}$ & $\begin{array}{l}\text { Colonoscopy } \\
\text { Initiate at age } 25 \\
\text { Repeat colonoscopy annually } \\
\text { If CRC, subtotal colectomy }\end{array}$ \\
\hline $\begin{array}{l}\text { Extracolonic cancers: } \\
\text { Most Common: } \\
\text { Endometrial }\end{array}$ & $\begin{array}{l}\text { Endometrial aspiration semi-annually, } \\
\text { Transvaginal US }\end{array}$ \\
\hline Ovary & $\begin{array}{l}\text { Transvaginal US, Doppler color } \\
\text { blood flow imagery, CA-125 } \\
\text { and repeat annually }\end{array}$ \\
\hline Stomach & $\begin{array}{l}\text { pper endoscopy, particularly in } \\
\text { Orient (Japan, Korea) or families } \\
\text { with gastric cancer, repeat annually }\end{array}$ \\
\hline Hepatobiliary, small bowel, pancreas & $\begin{array}{l}\text { No practical screening with acceptable } \\
\text { sensitivity/specificity }\end{array}$ \\
\hline $\begin{array}{l}\text { Upper uroepithelial tract (ureter, } \\
\text { and/or renal pelvis) }\end{array}$ & $\begin{array}{l}\text { Urine cytology, US, positive FH of lesions, } \\
\text { families with MTS }\end{array}$ \\
\hline Brain & $\begin{array}{l}\text { Positive } \mathrm{FH} \text {, but no known } \\
\text { screening efficacy }\end{array}$ \\
\hline $\begin{array}{l}\text { Sebaceous adenomas, } \\
\text { sebaceous carcinomas, } \\
\text { multiple keratoacanthomas (MTS) }\end{array}$ & $\begin{array}{l}\text { Cutaneous beacon to screen family for } \\
\text { Lynch syndrome tumors, coupled with } \\
\text { meticulous cutaneous examinations }\end{array}$ \\
\hline $\begin{array}{l}\text { Distinguishing pathology features: } \\
\text { Poorly differentiated, mucinous features } \\
\text { with signet cell excess, increased diploidy, } \\
\text { tumor infiltrating lymphocytes, lymphocytic } \\
\text { infiltration at periphery, Crohn's-like reaction, } \\
\text { increased diploidy }\end{array}$ & Useful for diagnosis \\
\hline $\begin{array}{l}\text { MMR mutations } \\
\text { Most common: } \\
\text { MLH1, MSH2, MSH6 }\end{array}$ & Enable certainty in diagnosis \\
\hline Survival advantage & $\begin{array}{l}\text { Evidence which may be useful for genetic } \\
\text { counseling }\end{array}$ \\
\hline $\begin{array}{l}\text { viations: } \\
\text { CRC: colorectal cancer } \\
\text { FH: family history } \\
\text { MMR: mismatch repair } \\
\text { MSI: microsatellite instability } \\
\text { MTS: Muir-Torre syndrome } \\
\text { US: ultrasound }\end{array}$ & \\
\hline
\end{tabular}

Fig. 3b. Algorithm showing proposed diagnosis and management procedures for Lynch syndrome families.

\section{Microsatellite instability (MSI)}

The mentioned new concept of microsatellite instability (MSI) has further provided powerful clues to CRC's carcinogenic pathways and therein it may become a diagnostic aid in the Lynch syndrome and perhaps other disorders yet to be described. For example, Lindblom [75] has described the consequences of genomic instability with respect to distinctive mechanisms involved in proximal and distal CRC. 
Jass [76] has provided a review of MSI in CRC with particular attention to the significance of MSI-H in socalled "early-onset" of "sporadic" CRC. He reasons that the molecular profile of early-onset MSI-H CRCs resemble that of HNPCC cancers, even in those cases where Amsterdam criteria fail to be met. Therein, Jass suggests that there are five cogent and interrelated reasons for questioning the presumption that early-onset "sporadic" MSI-H CRCs are truly sporadic: “. . . First is the fact that the incidence of HNPCC peaks at around 45 years. Second is the finding of germline mutations in DNA mismatch repair genes in subjects presenting with early-onset "sporadic" MSI-H colorectal cancer. Third is the evidence that methylation of $h M L H I$ in sporadic MSI-H cancer is strongly age-related. Fourth is the fact that methylation of $h M L H 1$ may occur selectively in HNPCC cancers in subjects who carry a germline mutation in $h M L H 1$. Fifth is the finding of HNPCCtype molecular features among early-onset "sporadic" MSI-H colorectal cancers." Jass [76] appropriately concludes that even the absence of a positive family history should not negate the diagnosis of HNPCC in patients with early-onset CRC characterized by MMR deficiency.

\section{International collaborative group on HNPCC (ICG-HNPCC)}

In 1989, the International Collaborative Group on Hereditary Nonpolyposis Colorectal Cancer (ICGHNPCC) was formed to encourage collaborative research studies. In 1991, this group published the rather stringent Amsterdam criteria for HNPCC, which focused exclusively on CRC [24]. These were followed in 1999 by the Amsterdam criteria II [25], which take into account extracolonic cancers that are integral to Lynch syndrome. The international collaboration activities through the ICG-HNPCC have also contributed to the development of a database of identified Lynch syndrome mutations [77], which can be found on the organization's website: http://www.nfdht.nl/. The Bethesda Guidelines followed and were developed to decrease the stringency of the Amsterdam Criteria I and II [26], and make them more useful to clinicians. The guidelines are reviewed in Table 2.

\section{International events and the Lynch syndrome}

A series of international studies had documented the existence of "cancer families" in countries around the world, including England [78], New Zealand [79], the Netherlands [80], Italy [81], Israel [82], Finland [83], and Uruguay [84]. The Finnish group, by virtue of its access to a population-based cancer registry, was able to demonstrate that the Lynch syndrome was not rare in that country [85]. During this phase of international recognition, the term hereditary nonpolyposis colorectal cancer (HNPCC) came into use. With increased acknowledgment of the importance of extracolonic cancers in the syndrome, coupled with the fact that colonic adenomas do occur in HNPCC, the eponym Lynch syndrome has now become the more accepted terminology [86].

\section{Lynch syndrome in South America}

Research on Lynch syndrome is ongoing in South America (Uruguay, Argentina, Brazil, and Colombia). These initial investigations began in Montevideo, Uruguay, with a Lynch syndrome family [84,87]. This Uruguayan family was first described in 1977 by Sarroca [84]. Beginning in 1995 [87], the colorectal cancer genetics research team from Creighton University made a series of visits to Uruguay during which time the studies of this original family were extended. Subsequently, the $M L H 1$ germline mutation was found in the family, segregating in accord with the expected autosomal dominant mode of genetic transmission [87]. Recommendations for surveillance and management were provided. Attention given to this extended family has had a positive impact on the physician community in Uruguay, leading to the identification of additional HNPCC families. Three novel germline mutations which predispose to Lynch syndrome II have been identified in the initial three extended Lynch syndrome kindreds studied in Uruguay [88].

During visits to Uruguay by the Lynch team, techniques for conducting family studies were demonstrated, inclusive of the FIS [12]. Several colorectal surgeons from Argentina and Brazil also attended. These studies have since led to the identification of a large number of Lynch syndrome kindreds throughout these South American countries. These efforts were then extended to studies of the Lynch syndrome in Argentina [89] and Colombia, again through an invitation extended to us by colorectal surgeons in those countries. 


\section{Finnish HNPCC founder mutation experience}

Precedent for the phenomenon of a founder effect in HNPCC originated with de la Chapelle and Wright [90], who evaluated two founder mutations in the $M L H 1$ gene in Finland. These mutations accounted for approximately half of all HNPCC families in that country [91,92]. These authors found that extensive haplotype sharing, “. . over a genomic region as large as $18 \mathrm{~cm}$ indicated a relatively recent founding of the more prevalent mutation. ... [wherein] the 'age' of this mutation in most of the 19 kindreds studied could be estimated at 16-43 generations in keeping with historical records and compatible with a founding in a regional subisolate in new Finland in the early 1500s [91, 93]."

Potential cancer control implications from this research abound. These dominant inherited founder mutations spread and their incidence was found to be so high in specific geographic regions of Finland that it constituted a unique public health problem. As these mutations became more readily understood and characterized, efficient screening for them at the population level became possible. Importantly, recognition of these mutations in a patient and his/her family could then signify individuals who could potentially benefit from highly-targeted educational and cancer screening programs [94]. Major public health implications for the diagnosis and, ultimately, prevention of cancer in HNPCC among founder mutation carriers require serious attention by clinical investigators and practicing clinicians [11].

\section{Lynch syndrome in the Navajo}

The Navajo are a subgroup of the Athabascan linguistic group, who migrated to the southwestern United States from eastern Alaska and Canada about 1000-1200 A.D. [95]. It is estimated that approximately 150,000 Navajo reside in New Mexico and Arizona [95].

In 1983, Thomas Drouhard, M.D., a general surgeon at the Public Health Service Hospital in Tuba City, Arizona, referred a Navajo family to Creighton University (Dr. Lynch). The proband had been diagnosed with ovarian carcinoma and a year later with carcinoma of the cecum. Dr. Drouhard had treated other family members who showed a marked excess of CRC in the absence of multiple colonic adenomas. The pedigree was consonant with Lynch syndrome [15,96] (Fig. 4).
The excess CRC occurrences in this family was especially interesting because of the known paucity of CRC in the Navajo when compared to the general population $[97,98]$.

In collaboration with Dr. Drouhard and his Navajo paramedicals, Lynch and his cancer genetics research team visited Tuba City, Arizona, on several occasions to provide information to the family about the syndrome and to obtain blood specimens, skin biopsies, and colonic mucosal biopsies for basic medical genetic research studies of this family. A mutation of a mutL homolog- $M L H 1$ germline mutation was identified by molecular genetic colleagues in 1994 [99]. In the following year, we provided DNA-based genetic counseling to 23 family members, 7 of whom were positive for the $M L H 1$ mutation [96]. Their reactions ranged from full acceptance of the genetic implications to certain more traditional Navajo concepts such as, "Our family has been cursed."

Following the identification of the $M L H 1$ germline mutation in this original Navajo family, the investigators began seeking other nuclear families throughout the Navajo reservation in southeast Arizona and northern New Mexico. The same $M L H 1$ mutation was found in four presumably unrelated families. These findings were strongly suggestive of a founder effect with the MLH1 gene. Specifically, sequence analysis of the MLH1 gene revealed a 4-base-pair deletion beginning at the first nucleotide of codon 727 which predicts a frameshift and a substitution of new amino acids to the COOH-terminus of the protein [65].

Many of the Navajo live on reservation lands, where they have undergone relatively little genetic mixing with other racial groups. This racial homogeneity and the generally common environmental exposures of reservation life make it likely that the evaluation of cancer family history and lifestyle among the Navajo could elicit important epidemiologic clues about host and environmental interaction in cancer etiology. Prospective studies using the $M L H 1$ founder mutation identified in these Navajo families could facilitate such geneticepidemiologic research [99]. This would allow the identification of environmental exposures in concert with knowledge of who is versus who is not inordinately predisposed to cancer.

\section{North American founder mutation}

Lynch et al. [100] have described another example of the founder mutation phenomenon. This involves a mu- 

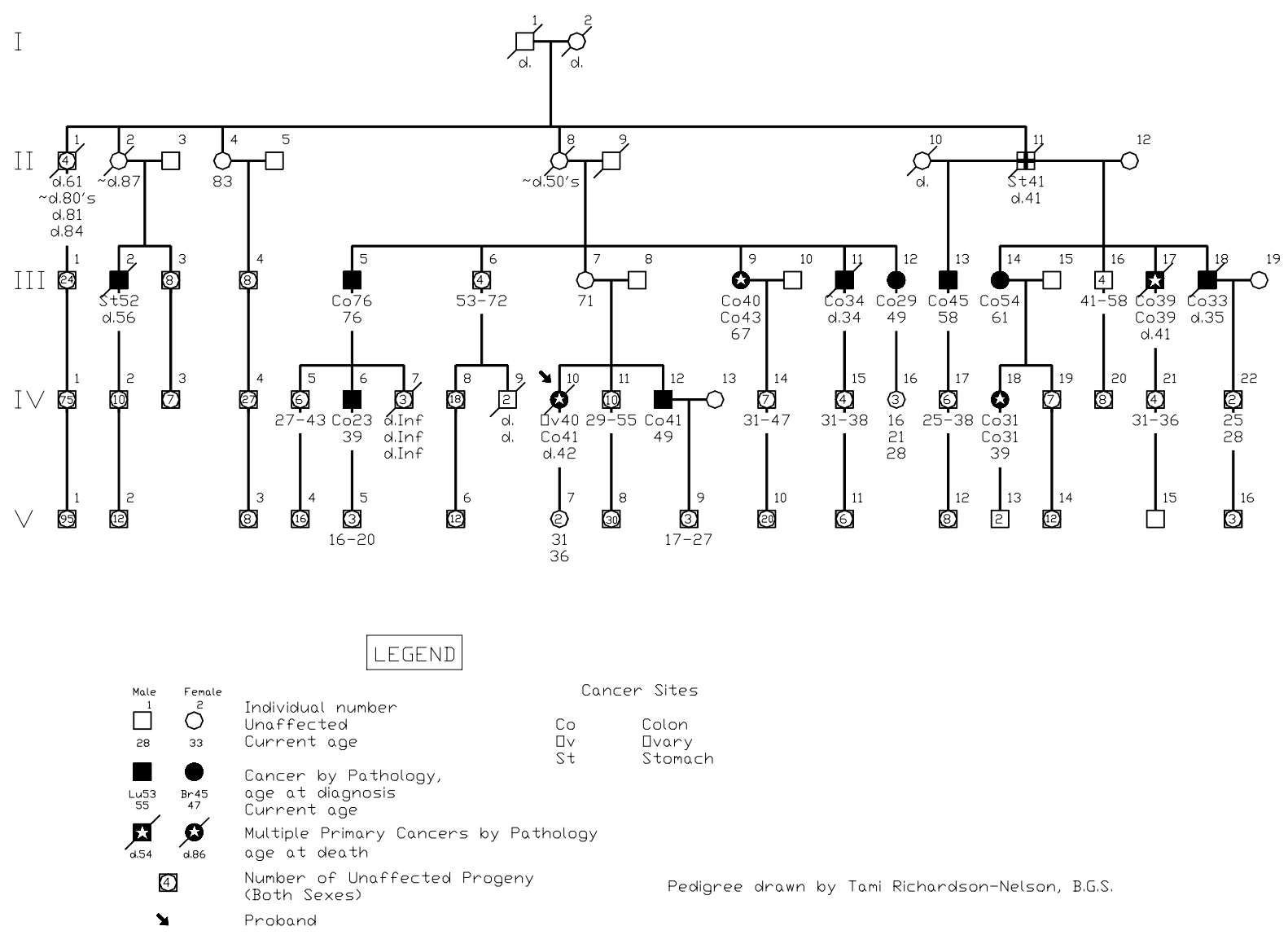

Fig. 4. Pedigree of Navajo family with $M L H 1$ mutation. (Adapted with permission from Lynch et al. Cancer 1996;77:30-35.) Lynch and Lynch/Page 12.

tation, namely $M L H 2$ del [1-6], in nine families which have been tracked from their "founder" in Germany in the eighteenth century through their migrations to and within the United States until the present day [101].

Founder mutation studies have many advantages compared to genetic testing in unrelated populations, including more efficient identification of relatives who are at increased hereditary cancer risk and who thereby can benefit from genetic counseling in concert with highly targeted surveillance and management.

\section{Discussion}

We have attempted to describe many of the important historical landmarks of the Lynch syndrome (HNPCC), the most commonly occurring hereditary syndrome that predisposes to CRC [11]. HNPCC is complex, and thereby, during the past decade, diagnostic guidelines for HNPCC have been modified significantly [24-26], as have advances in surveillance, management $[11,35$,
94], and molecular genetic testing [7,71]. Needed is greater understanding of the ethical and malpractice issues that impact on these concerns [102], and of the barriers to its diagnosis, management, and compliance of at-risk patients.

The original definitions of HNPCC based upon clinical and pedigree criteria such as the more stringent Amsterdam criteria [24] or the less stringent Amsterdam II criteria [25] are valid today. However, in many situations the occurrence of HNPCC-associated cancers, especially in small families, cancer of markedly early onset, or the pattern of multiple cancers in any single individual, should alert the clinician to the possibility of HNPCC.

\section{What the physician needs to know: CRC as a model}

Calvert and Frucht [103] stress the need for physicians to understand the molecular causes of CRC, with 
particular recognition of the variation in cancer phenotypes, in the quest for improved cancer screening and appropriate genetic testing in the interest of prevention.

Soravia et al. [104] note how the causative genes for the several hereditary CRC-prone syndromes have become widely used for confirming their clinical diagnosis. Thus, genetic testing may provide indications for targeted surveillance of at-risk family members and, conversely, may allow those family members who are not harbingers of the deleterious gene present in the family to avoid this intensive surveillance and management. These issues are particularly important in the management of the Lynch syndrome because, with the single exception of the cutaneous stigmata of the MTS, there are no obvious phenotypic physical stigmata that will aid in its diagnosis. Therefore, the diagnostician must continue to rely heavily upon the family history, cancer phenotype, pathology findings and, when available, the presence of cancer-causing Lynch syndrome MMR mutations (Fig. 3).

Chemoprevention and chemotherapy in the management of the Lynch syndrome remain challenging areas of concern, with new knowledge having the potential to impact every area of cancer management and treatment. For example, the findings of Ribic et al. [60] suggest that while adjuvant therapy with 5-fluorouracil improved survival among CRC patients (stage II and stage III) with MSI-stable and MSI-low tumors, it had no benefit for those with MSI-high tumors.

\section{Cancer control in lynch syndrome}

Järvinen and colleagues [94] demonstrated the benefit of colonoscopic screening in HNPCC through a controlled clinical trial extending over 15 years. The incidence of CRC was compared in two cohorts of atrisk members of $22 \mathrm{HNPCC}$ families. CRC developed in eight screened subjects (6\%), compared with 19 unscreened controls $(16 \% ; p=0.014)$. The CRC rate was reduced by $62 \%$ in those who were screened. All CRCs in the screened group were local, causing no deaths, compared with nine deaths caused by CRC in the controls. It was concluded that CRC screening at three-year intervals more than cuts in half the risk of CRC, prevents CRC deaths, and decreases overall mortality by about $65 \%$ in HNPCC families. The relatively high incidence of CRC even in the screened subjects (albeit without deaths) in our opinion argues for shorter screening intervals, e.g., one year. For example, Vasen and colleagues [105] discovered five interval cancers in
HNPCC patients within 3-1/2 years following a normal colonoscopy.

In reviewing this subject, Church [106] suggests that interval CRCs develop from normal epithelium within three years and/or from adenomas that were missed. It is also important to realize that colonoscopy "miss" rates are as high as $29 \%$ for polyps $<5 \mathrm{~mm}$ in diameter [107]. Patients should, therefore, be advised that colonoscopy, while not a perfect screening procedure, is, nevertheless, highly effective [94]. The option of prophylactic colectomy should be discussed [108,109], particularly in non-compliant patients, as described below.

\section{Prophylactic colectomy}

Subtotal colectomy as a prophylactic measure among HNPCC patients remains controversial. However, in special circumstances, patients who carry germline MMR cancer-causing mutations should be offered this option as an alternative to lifetime colonoscopic surveillance. Genetic counseling, coupled with a second surgical opinion, must be provided so that patients can be in the best possible position to evaluate the various available surgical management strategies. Church109 and Lynch108 have suggested that prophylactic surgery should be an option for those patients likely to show reduced compliance for colonoscopy.

Some authors [110-113] have found the $70 \%$ to $80 \%$ lifetime risk of developing CRC to be a compelling rationale for prophylactic surgery, while others disagree [114-117]. Clearly, prophylactic colectomy should be offered only in selected situations, such as in a mutation carrier who completely refuses colonoscopy surveillance. The patient must understand that after surgery, surveillance of the remaining rectal segment will need to be performed annually with sigmoidoscopy [110]. We argue that prophylactic colectomy in Lynch syndrome, while an unsettled problem begging for a scientific evidence-based answer, must be individualized in accordance with the patient's best posits for cancer control.

Syngal and colleagues [115] examined the life expectancy and quality-adjusted life expectancy benefits resulting from endoscopic surveillance and prophylactic colectomy among carriers of germline mutations for HNPCC. Both risk-reduction programs showed large gains in life expectancy for mutation carriers, with benefits of 13.5 years for surveillance and 15.6 years for prophylactic proctocolectomy at 25 years of age, compared with no intervention. The benefits of prophylactic colectomy decreased with increasing age. 


\section{Prophylactic hysterectomy and oophorectomy in Lynch syndrome}

Women at risk for the Lynch syndrome should have annual screening for endometrial and ovarian cancer beginning at age 30 to 35 years. Endometrial aspiration coupled with transvaginal ultrasound is advised for screening. CA 125 testing should be performed semiannually for ovarian cancer. Women must be advised of the marked limitations in ovarian cancer screening. Prophylactic hysterectomy and oophorectomy can be considered when childbearing is completed.

\section{Future projections}

Finally, there remain countless areas in the etiology, pathogenesis, and control of HNPCC that will require continued intensive research. Some of the questions to be answered are: 1) What is the complete tumor complement of HNPCC? 2) What are the chemotherapy and chemoprevention implications of this disease? 3) Can we improve surveillance/management strategies? 4) Can we achieve molecular-based chemoprevention? 5) What are the genotypic and phenotypic heterogeneity implications of Lynch syndrome? 6) What are the differential diagnostic implications?

Our efforts and those of colleagues throughout the world have only grazed the tip of the iceberg in terms of the etiology, pathogenesis, surveillance, and management of Lynch syndrome. What is known in high relief is that the knowledge accrued to date, when translated clinically, can save lives!

\section{Acknowledgements}

This chapter was supported by revenue from $\mathrm{Ne}$ braska cigarette taxes awarded to Creighton University by the Nebraska Department of Health and Human Services. Its contents are solely the responsibility of the authors and do not necessarily represent the official views of the State of Nebraska or the Nebraska Department of Health and Human Services.

Support was also received from NIH Grant \#1U01 CA86389, and through a grant awarded by the Jacqueline Seroussi Memorial Foundation.

\section{References}

[1] International Agency for Research on Cancer, Globocan 2000, International Agency for Research on Cancer, Available at: http://www-dep.iarc.fr/globocan/globocan.html. Accessed March 26, 2003.

[2] S.J. Laken, G.M. Petersen, S.B. Gruber, C. Oddoux, H. Ostrer and F.M. Giardiello et al., Familial colorectal cancer in Ashkenazim due to a hypermutable tract in APC, Nat Genet 17 (1997), 79-83.

[3] N. Al-Tassan, N.H. Chmiel, J. Maynard and N. Fleming, Inherited variants of MYH associated with somatic G:C $\rightarrow$ T:A mutations in colorectal tumors, Nat Genet 30 (2002), 227-232.

[4] O.M. Sieber, L. Lipton, M. Crabtree, K. Heinimann, P. Fidalgo and R.K.S. Phillips et al., Multiple colorectal adenomas, classic adenomatous polyposis, and germline mutations in MYH, $N$ Engl J Med 348 (2003), 791-799.

[5] H.T. Lynch, A.J. Krush and H. Guirgis, Genetic factors in families with combined gastrointestinal and breast cancer, Am J Gastroenterol 59 (1973), 31-40.

[6] H. Meijers-Heijboer, J. Wijnen, H. Vasen, M. Wasielewski, A. Wagner and A. Hollestelle et al., The CHEK2 1100delC mutation identifies families with a hereditary breast and colorectal cancer phenotype, Am J Hum Genet 72 (2003), 13081314.

[7] B. Vogelstein and K.W. Kinzler, eds, The Genetic Basis of Human Cancer, New York: McGraw-Hill, 1998.

[8] T.C. Smyrk and H.T. Lynch, Microsatellite instability: impact on cancer progression in proximal and distal colorectal cancers, Eur J Cancer 35 (1999), 171-172.

[9] J.A. Bufill, Colorectal cancer: evidence for distinct genetic categories based on proximal or distal tumor location, Ann Intern Med 113 (1990), 779-788.

[10] O.K. Glebov, L.M. Rodriguez, K. Nakahara, J. Jenkins, J. Cliatt and C-J. Humbyrd et al., Distinguishing right from left colon by the pattern of gene expression, Cancer Epidemiol Biomarkers Prev 12 (2003), 755-762.

[11] H.T. Lynch and A. de la Chapelle, Genomic medicine: hereditary colorectal cancer, N Engl J Med 348 (2003), 919-932.

[12] H.T. Lynch, Family Information Service and hereditary cancer, Cancer 91 (2001), 625-628.

[13] P. Watson and H.T. Lynch, Extracolonic cancer in hereditary nonpolyposis colorectal cancer, Cancer 71 (1993), 677-685.

[14] P. Watson and H.T. Lynch, The tumor spectrum in HNPCC, Anticancer Res 14 (1994), 1635-1640.

[15] H.T. Lynch, M.W. Shaw, C.W. Magnuson, A.L. Larsen and A.J. Krush, Hereditary factors in cancer: study of two large Midwestern kindreds, Arch Intern Med 117 (1966), 206-212.

[16] H.T. Lynch and A.J. Krush, Cancer family G revisited: 18951970, Cancer 27 (1971), 1505-1511.

[17] S.S. Chang and W.H. Hildemann, Inheritance of susceptibility to polyoma virus in mice, J Natl Cancer Inst 33 (1964), 303-313.

[18] A.S. Warthin, Heredity with reference to carcinoma as shown by the study of the cases examined in the pathological laboratory of the University of Michigan, 1895-1913, Arch Intern Med 12 (1913), 546-555.

[19] H. Yan, N. Papadopoulos, G. Marra, C. Perrera, J. Jiricny and C.R. Boland et al., Conversion of diploidy to haploidy: individuals susceptible to multigene disorders may now be spotted more easily, Nature 403 (2000), 723-724.

[20] H.T. Lynch and A.J. Krush, The cancer family syndrome and cancer control, Surg Gynecol Obstet 132 (1971), 247-250. 
[21] H.T. Lynch, A.J. Krush and A.L. Larsen, Heredity and multiple primary malignant neoplasms: six cancer families, $A m$ J Med Sci 254 (1967), 322-329.

[22] P.M. Lynch, H.T. Lynch and R.E. Harris, Hereditary proximal colonic cancer, Dis Colon Rectum 20 (1977), 661-668.

[23] M. Lipkin, W.E. Blattner, J.F. Fraumeni, Jr., H.T. Lynch, E. Deschner and S. Winawer, Tritiated thymidine (phi p, phi h) labeling distribution as a marker for hereditary predisposition to colon cancer, Cancer Res 43 (1983), 1899-1904.

[24] H.F.A. Vasen, J-P. Mecklin, P. Meera Khan and H.T. Lynch, The International Collaborative Group on Hereditary Nonpolyposis Colorectal Cancer (ICG-HNPCC), Dis Colon Rectum 34 (1991), 424-425.

[25] H.F.A. Vasen, P. Watson, J-P. Mecklin and H.T. Lynch, ICGHNPCC. New clinical criteria for hereditary nonpolyposis colorectal cancer (HNPCC, Lynch syndrome) proposed by the International Collaborative Group on HNPCC, Gastroenterology 116 (1999), 1453-1456.

[26] M.A. Rodriguez-Bigas, C.R. Boland, S.R. Hamilton, D.E. Henson, J.R. Jass and P.M. Khan et al., A National Cancer Institute workshop on hereditary nonpolyposis colorectal cancer syndrome: meeting highlights and Bethesda Guidelines, J Natl Cancer Inst 89 (1997), 1758-1762.

[27] W.A. Albano, J.A. Recabaren, H.T. Lynch, A.S. Campbell, J.A. Mailliard and C.H. Organ et al., Natural history of hereditary cancer of the breast and colon, Cancer 50 (1982), 360 363.

[28] H.T. Lynch, P. Watson, S.J. Lanspa, J.N. Marcus, T.C. Smyrk and R. Fitzgibbons, Jr. et al., Natural history of colorectal cancer in hereditary nonpolyposis colorectal cancer (Lynch Syndromes I and II), Dis Colon Rectum 31 (1988), 439-444.

[29] H.T. Lynch, K. Lin, T. Smyrk, P. Watson, A. Thorson and M. Shashidharan et al., Colorectal cancer, pathology staging and survival in HNPCC, ASCO Program/Proceedings 16 (1997), 530a, Abstract.

[30] P. Watson, K. Lin, M.A. Rodriguez-Bigas, T. Smyrk, S. Lemon and M. Shashidharan et al., Colorectal carcinoma survival among hereditary nonpolyposis colorectal cancer family members, Cancer 83 (1998), 259-266.

[31] J.R. Jass, T.C. Smyrk, S.M. Stewart, M.R. Lane, S.J. Lanspa and H.T. Lynch, Pathology of hereditary non-polyposis colorectal cancer, Anticancer Res 14 (1994), 1631-1634.

[32] T.C. Smyrk, P. Watson, K. Kaul and H.T. Lynch, Tumorinfiltrating lymphocytes are a marker for microsatellite instability in colorectal cancer, Cancer 91 (2001), 2417-2422.

[33] J.I. Risinger, J.C. Barrett, P. Watson, H.T. Lynch and J. Boyd, Molecular genetic evidence of the occurrence of breast cancer as an integral tumor in patients with the hereditary nonpolyposis colorectal cancer syndrome, Cancer 77 (1996), 1836-1843.

[34] Y.J. Park, K-H. Shin and J-G. Park, Risk of gastric cancer in hereditary nonpolyposis colorectal cancer in Korea, Clin Cancer Res 6 (2000), 2994-2998.

[35] H.T. Lynch and A. de la Chapelle, Genetic susceptibility to non-polyposis colorectal cancer, J Med Genet 36 (1999), 801-818.

[36] J.R. Jass and S.M. Stewart, Evolution of hereditary nonpolyposis colorectal cancer, Gut 33 (1992), 783-786.

[37] J.R. Jass, Colorectal adenoma progression and genetic change: is there a link? Ann Med 27 (1995), 301-306.

[38] H.T. Lynch, P.M. Lynch, J. Pester and R.M. Fusaro, The cancer family syndrome: rare cutaneous phenotypic linkage of Torre's syndrome, Arch Intern Med 141 (1981), 607-611.
[39] H.T. Lynch, P.M. Lynch, J.A. Pester and R.M. Fusaro, Sebaceous neoplasia and visceral cancer (Torre's syndrome) and its relationship to the cancer family syndrome, in: Cancerassociated Genodermatoses, H.T. Lynch and R.M. Fusaro, eds, New York: Van Nostrand Reinhold, 1982, pp. 366-393.

[40] H.T. Lynch, R.M. Fusaro, L. Roberts, G.J. Voorhees and J.F. Lynch, Muir-Torre syndrome in several members of a family with a variant of the cancer family syndrome, $\mathrm{Br} J$ Dermatol 113 (1985), 295-301.

[41] H.T. Lynch and R.M. Fusaro, Muir-Torre syndrome: heterogeneity, natural history, diagnosis, and management, Prob Gen Surg 10 (1993), 1-14.

[42] H.T. Lynch, R. Leibowitz, T. Smyrk, R.M. Fusaro, J.F. Lynch and A. Smith et al., Colorectal cancer and the Muir-Torre syndrome in a Gypsy family: a review, Am J Gastroenterol 94 (1999), 575-580.

[43] J.R. Jass, S.M. Stewart, J. Stewart and M.R. Lane, Hereditary nonpolyposis colorectal cancer - morphologies, genes and mutations, Mutation Res 310 (1994), 125-133.

[44] J.R. Jass, Natural history of hereditary non-polyposis colorectal cancer, Journal of Tumor Marker Oncology 10 (1995), 65-71.

[45] R. Sankila, L.A. Aaltonen, H.J. Jarvinen and J-P. Mecklin, Better survival rates in patients with $M L H 1$-associated hereditary colorectal cancer, Gastroenterology 110 (1996), 682687.

[46] J-P. Mecklin and H.J. Jarvinen, Clinical features of colorectal carcinoma in cancer family syndrome, Dis Colon Rectum 29 (1986), 160-164.

[47] H.T. Lynch, T. Smyrk, S. Lanspa, J. Marcus, B.M. Bowman and P. Watson et al., Pathology and genetic markers of colorectal cancer in Lynch Syndromes I and II, J Tumor Marker Oncol 3 (1988), 341-350.

[48] N.M. Gibbs, Undifferentiated carcinoma of the large intestine, Histopathology 1 (1977), 77-84.

[49] M.R. Jessurun and J.C. Manivel, Cecal, poorly differentiated adenocarcinomas, medullary-type, Mod Pathol 5 (1992), 43A, Abstract.

[50] H. Kim, J. Jen, B. Vogelstein and S.R. Hamilton, Clinical and pathological characteristics of sporadic colorectal carcinomas with DNA replication errors in microsatellite sequences, Am J Pathol 145 (1994), 148-156.

[51] S.N. Thibodeau, A.J. French, P.C. Roche, J.M. Cunningham, D.J. Tester and N.M. Lindor et al., Altered expression of hMSH2 and hMLH1 in tumors with microsatellite instability and genetic alterations in mismatch repair genes, Cancer Res 56 (1996), 4836-4840.

[52] T.C. Smyrk, H.T. Lynch, P.A. Watson and H.D. Appelman, Histologic features of hereditary nonpolyposis colorectal carcinoma, in: Hereditary Colorectal Cancer, J. Utsunomiya and H.T. Lynch, eds, Tokyo: Springer-Verlag, 1990, pp. 357362.

[53] D.M. Graham and H.D. Appelman, Crohn's-like lymphoid reaction and colorectal carcinoma: a potential histologic prognosticator, Mod Pathol 3 (1990), 332-335.

[54] R. Gryfe, H. Kim, E.T.K. Hsieh, M.D. Aronson, E.J. Holowaty and S.B. Bull et al., Tumor microsatellite instability and clinical outcome in young patients with colorectal cancer, N Engl J Med 342 (2000), 69-77.

[55] K.M. Lin, M. Shashidharan, C.A. Ternent, A.G. Thorson, G.J. Blatchford and M.A. Christensen et al., Colorectal and extracolonic cancer variations in $M L H 1 / \mathrm{MSH} 2$ hereditary nonpolyposis colorectal cancer kindreds and the general population, Dis Colon Rectum 41 (1998), 428-433. 
[56] P. Peltomäki, L. Aaltonen, P. Sistonen, L. Pylkkänen, J-P. Mecklin and H. Järvinen et al., Genetic mapping of a locus predisposing to human colorectal cancer, Science 260 (1993), 810-812.

[57] A. Lindblom, P. Tannergard, B. Werelius and M. Nordenskjold, Genetic mapping of a second locus predisposing to hereditary nonpolyposis colorectal cancer, Nat Genet $\mathbf{5}$ (1993), 279-282.

[58] L.A. Aaltonen, P. Peltomaki, F.S. Leach, P. Sistonen, L. Pylkkanen and J-P. Mecklin et al., Clues to the pathogenesis of familial colorectal cancer, Science 260 (1993), 812-816.

[59] S.N. Thibodeau, G. Bren and D. Schaid, Microsatellite instability in cancer of the proximal colon, Science 260 (1993), 816-819.

[60] C.M. Ribic, D.J. Sargent, M.J. Moore, S.N. Thibodeau, A.J. French and R.M. Goldberg et al., Tumor microsatelliteinstability status as a predictor of benefit from fluorouracilbased adjuvant chemotherapy for colon cancer, $N$ Engl J Med 349 (2003), 247-257.

[61] A. de la Chapelle, Microsatellite instability, $N$ Engl J Med 349 (2003), 209-210

[62] R. Fishel, M.K. Lescoe, M.R.S. Rao, N.G. Copeland, N.A. Jenkins and J. Garber et al., The human mutator gene homolog $M L H 2$ and its association with hereditary nonpolyposis colon cancer, Cell 75 (1993), 1027-1038.

[63] F.S. Leach, N.C. Nicolaides, N. Papadopoulos, B. Liu, J. Jen and R. Parsons et al., Mutations of a mutS homolog in hereditary nonpolyposis colorectal cancer, Cell 75 (1993), 1215-1225.

[64] C.E. Bronner, S.M. Baker, P.T. Morrison, G. Warren, L.G. Smith and M.K. Lescoe et al., Mutation in the DNA mismatch repair gene homologue hMLH1 is associated with hereditary nonpolyposis colon cancer, Nature 368 (1994), 258-261.

[65] N. Papadopoulos, N.C. Nicolaides, Y-F. Wei, S.M. Ruben, K.C. Carter and C.A. Rosen et al., Mutation of a mutL homolog in hereditary colon cancer, Science 263 (1994), 16251629.

[66] F. Palombo, M. Hughes, J. Jiricny, O. Truong and J. Hsuan, Mismatch repair and cancer, Nature 367 (1994), 417.

[67] N.C. Nicolaides, N. Papadopoulos, B. Liu, Y-F. Wei, K.C. Carter and S.M. Ruben et al., Mutations of two PMS homologues in hereditary nonpolyposis colon cancer, Nature 371 (1994), 75-80.

[68] B. Liu, R.E. Parsons, S.R. Hamilton, G.M. Petersen, H.T Lynch and P. Watson et al., hMSH2 mutations in hereditary nonpolyposis colorectal cancer kindreds, Cancer Res $\mathbf{5 4}$ (1994), 4590-4594.

[69] R. Parsons, G.M. Li, M.J. Longley, W.-H. Fang, N. Papadopoulos and J. Jen et al., Hypermutability and mismatch repair deficiency in RER + tumor cells, Cell 75 (1993), 12271236.

[70] H.T. Lynch, T. Smyrk and J. Lynch, An update of HNPCC (Lynch syndrome), Cancer Genet Cytogenet 93 (1997), 8499.

[71] P. Peltomäki, Role of DNA mismatch repair defects in the pathogenesis of human cancer, J Clin Oncol 21 (2003), 11741179 .

[72] M. Miyaki, M. Konishi, K. Tanaka, R. Kikuchi-Yanoshita, M. Muraoka and M. Yasuno et al., Germline mutation of MSH6 as the cause of hereditary nonpolyposis colorectal cancer, Nat Genet 17 (1997), 271-272.

[73] J. Wijnen, W. de Leeuw, H. Vasen, H. van der Klift, P. Møller and A. Stormorken et al., Familial endometrial cancer in female carriers of MSH6 germline mutations, Nat Genet 23 (1999), 142-144.

[74] E. Renkonen, H. Lohi, Y. Zhang, R. Salovaara, W. AbdelRahman and A-L. Moisio et al., Expression changes in predisposition to HNPCC and FAP: a population based study, Familial Cancer 2(Suppl 1) (2003), 37, Abstract.

[75] A. Lindblom, Different mechanisms in the tumorigenesis of proximal and distal colon cancers, Curr Opin Oncol 13 (2001), 63-69.

[76] J.R. Jass, Clinical significance of early-onset sporadic colorectal cancer with microsatellite instability, Dis Colon Rectum 46 (2003), 1305-1309.

[77] J-G. Park, H.F.A. Vasen, Y.J. Park, K.J. Park, P. Peltomaki and M. Ponzo de Leon et al., Suspected HNPCC and Amsterdam criteria II: evaluation of mutation detection rate, an international collaborative study, Int J Colorectal Dis 17 (2002), $109-114$.

[78] H. Itoh, R.S. Houlston, C. Harocopos and J. Slack, Risk of cancer death in first-degree relatives of patients with hereditary nonpolyposis cancer syndrome (Lynch Type II): a study of 130 kindreds in the United Kingdom, Br J Surg 77 (1990), 1367-1370.

[79] J.R. Jass, S.M. Stewart, D. Schroeder and M.R. Lane, Screening for hereditary nonpolyposis colorectal cancer in New Zealand, Eur J Gastroenterol Hepatol 4 (1992), 523-527.

[80] H.F. Vasen, F.C.A. Hartog Jager, F.H. Menko and F.M. Nagengast, Screening for hereditary nonpolyposis colorectal cancer: a study of 22 kindreds in the Netherlands, Am J Med 86 (1989), 278-281.

[81] M. Ponz de Leon, R. Sassatelli, C. Sacchetti, G. Zanghieri, A. Scalmati and L. Roncucci, Familial aggregation of tumors in the 3-year experience of a population-based colorectal cancer registry, Cancer Res 49 (1989), 4344-4348.

[82] H. Abusamra, S. Maximova, S. Bar-Meir, M. Krispin and H.H. Rotmensch, Cancer family syndrome of Lynch, Am J Med 83 (1987), 981-983.

[83] J-P. Mecklin, H.J. Jarvinen and P. Peltokallio, Cancer family syndrome: genetic analysis of 22 Finnish kindreds, Gastroenterology 30 (1986), 328-333.

[84] C. Sarroca, W.A. Ferreira and R. Quadrelli, Cáncer colónico familiar sin poliposis: enfoque clínico y anátomo-patológico, Perspectivas de estudio genético, Cir del Uruguay 47 (1977), 515-520.

[85] J.P. Mecklin, Frequency of hereditary nonpolyposis colorectal carcinoma, Gastroenterology 93 (1987), 1021-1025.

[86] National Institutes of Health, The diagnostic guidelines for hereditary non-polyposis colorectal cancer and microsatellite instability meeting. 03 Dec 11; NIH, 2002.

[87] C. Sarroca, N. Alfano, G.T. Bendin, A. Della Valle, C. Dominguez and R. Quadrelli et al., Hereditary nonpolyposis colorectal cancer (Lynch syndrome II) in Uruguay, Dis Colon Rectum 43 (2000), 353-362.

[88] C. Sarroca, P. Peltomäki, N. Alfano, G. Tedesco, A. Della Valle and A. Dominguez et al., Three new mutations in hereditary nonpolyposis colorectal cancer (Lynch syndrome II) in Uruguay, Cancer Genet Cytogenet 142 (2003), 13-20.

[89] T.E. Raevaara, C. Vaccaro, W.M. Abdel-Rahman, E. Mocetti, S. Bala and K.E. Lönnqvist et al., Pathogenicity of the hereditary colorectal cancer mutation hMLH1 del616 linked to shortage of the functional protein, Gastroenterology 125 (2003), 501-509.

[90] A. de la Chapelle and F.A. Wright, Linkage disequilibrium mapping in isolated populations: the example of Finland revisited, Proc Natl Acad Sci USA 95 (1998), 12416-12423. 
[91] M. Nyström-Lahti, P. Sistonen, J-P. Mecklin, L. Pylkkänen, L.A. Aaltonen and H. Järvinen et al., Close linkage to chromosome $3 p$ and conservation of ancestral founding haplotype in hereditary nonpolyposis colorectal cancer families, Proc Natl Acad Sci USA 91 (1994), 6054-6058.

[92] M. Nyström-Lahti, Y. Wu, A-L. Moisio, R.M.W. Hofstra, J. Osinga and J-P. Mecklin et al., DNA mismatch repair gene mutations in 55 kindreds with verified or putative hereditary nonpolyposis colorectal cancer, Hum Mol Genet 5 (1996), 763-769.

[93] A-L. Moisio, P. Sistonen, J. Weissenbach, A. de la Chapelle and P. Peltomaki, Age and origin of two common $\mathrm{MLH1}$ mutations predisposing to hereditary colon cancer, Am J Hum Genet 59 (1996), 1243-1251.

[94] H.J. Järvinen, M. Aarnio, H. Mustonen, K. Aktan-Collan, L.A. Aaltonen and P. Peltomäki et al., Controlled 15-year trial on screening for colorectal cancer in families with hereditary nonpolyposis colorectal cancer, Gastroenterology 118 (2000), 829-834.

[95] D. Kluckhorn and D. Leighton, The Navajo. Cambridge, Mass.: Harvard University Press, 1974.

[96] H.T. Lynch, T. Drouhard, H.F.A. Vasen, J. Cavalieri, J. Lynch and S. Nord et al., Genetic counseling in a Navajo hereditary nonpolyposis colorectal cancer kindred, Cancer 77 (1996), 30-35.

[97] M.L. Sievers, Cancer of the digestive system among American Indians, Ariz Med 33 (1976), 15-20.

[98] E.T. Creagan and J.F. Fraumeni, Cancer mortality among American Indians, J Natl Cancer Inst 49 (1972), 959-967.

[99] H.T. Lynch, T. Drouhard, S. Lanspa, T. Smyrk, P. Lynch and J. Lynch et al., Mutation of an mutL homologue in a Navajo family with hereditary nonpolyposis colorectal cancer, J Natl Cancer Inst 86 (1994), 1417-1419.

[100] H.T. Lynch, S.M. Coronel, R. Okimoto, H. Hampel, K. Sweet and J.F. Lynch et al., An American founder mutation of the $M L H 2$ gene may account for a significant proportion of all Lynch syndrome cases in the United States, JAMA, in press.

[101] A. Wagner, H. van der Klift, P. Franken, J. Wijnen, C. Breukel and V. Bezrookove et al., A $10 \mathrm{Mb}$ paracentric inversion of chromosome arm 2p inactivates $M L H 2$ and is responsible for HNPCC in a North-American kindred, Genes Chromosomes Cancer 35 (2002), 49-57.

[102] H.T. Lynch, J. Paulson, M. Severin, J. Lynch and P. Lynch, Failure to diagnose hereditary colorectal cancer and its medicolegal implications: a hereditary nonpolyposis colorectal cancer case, Dis Colon Rectum 42 (1999), 31-35.

[103] P.M. Calvert and H. Frucht, The genetics of colorectal cancer, Ann Intern Med 137 (2002), 603-612.

[104] C. Soravia, T. Berk and Z. Cohen, Genetic testing and surgical decision making in hereditary colorectal cancer, Int $J$ Colorectal Dis 15 (2000), 21-28.

[105] H.F.A. Vasen, F.M. Nagengast and P.M. Khan, Interval cancers in hereditary non-polyposis colorectal cancer (Lynch syndrome), Lancet 345 (1995), 1183-1184.

[106] J. Church, Hereditary colon cancers can be tiny: a cautionary case report of the results of colonoscopic surveillance, Am J Gastroenterol 93 (1998), 2289-2290.

[107] D.K. Rex, C.S. Cutler, G.T. Lemmel, E.Y. Rahmani, D.W. Clark and D.J. Helper et al., Colonoscopic miss rates of adenomas determined by back-to-back colonoscopies, Gastroenterology 112 (1997), 24-28.

[108] H.T. Lynch, Is there a role for prophylactic subtotal colectomy among hereditary nonpolyposis colorectal cancer germline mutation carriers? Dis Colon Rectum 39 (1996), 109-110.

109] J.M. Church, Prophylactic colectomy in patients with hereditary nonpolyposis colorectal cancer, Ann Med 28 (1996), 479-482.

[110] C.L. Scaife and M.A. Rodriguez-Bigas, Lynch syndrome: Implications for the surgeon, Clinical Colorectal Cancer 3 (2003), 92-98.

[111] M.A. Rodriguez-Bigas and N.J. Petrelli, Management of hereditary colon cancer syndromes, in: Colorectal Cancer: Multimodality Management, L.B. Saltz, ed., Totowa, NJ: Humana Press, 2002, pp. 99-114.

[112] M.A. Rodriguez-Bigas, Prophylactic colectomy for gene carriers in hereditary nonpolyposis colorectal cancer, Has the time come? Cancer 78 (1996), 199-201.

[113] H.T. Lynch, J.F. Lynch and R. Fitzgibbons, Role of prophylactic colectomy in Lynch syndrome, Clinical Colorectal Cancer 3 (2003), 99-101.

[114] S.E. Green, D.M. Bradburn, J.S. Varma and J. Burn, Hereditary nonpolyposis colorectal cancer, Int J Colorectal Dis $\mathbf{1 3}$ (1998), 3-12.

[115] S. Syngal, J.C. Weeks, D. Schrag, J.E. Garber and K.M. Kuntz, Benefits of colonoscopic surveillance and prophylactic colectomy in patients with hereditary nonpolyposis colorectal cancer mutations, Ann Intern Med 129 (1998), 787796.

[116] S. Anwar, C. Hall, J. White, M. Deakin, W. Farrell and J.B. Elder, Hereditary nonpolyposis colorectal cancer: an updated review, Eur J Surg Oncol 26 (2000), 635-645.

[117] G. Möslein, S. Pistorius, H. Saeger and H.K. Schackert, Preventive surgery for colon cancer in familial adenomatous polyposis and hereditary nonpolyposis colorectal cancer syndrome, Langenbaecks Arch Surg 288 (2003), 9-16.

[118] A. Krush, H.T. Lynch and C. Magnuson, Attitudes toward cancer in a cancer family: implications for cancer detection, Am J Med Sci 249 (1965), 432-438.

[119] H.T. Lynch, R.L. Tips, A.J. Krush and C. Magnuson, Family centered genetic counseling: role of the physician and the medical genetics clinic, Nebr State Med J 50 (1965), 155.

[120] G. Cristofaro, H.T. Lynch, M.L. Caruso, A. Attolini, G. DiMatteo and P. Giorgio et al., New phenotypic aspects in a family with Lynch syndrome II, Cancer 60 (1987), 51-58.

[121] H.T. Lynch, P.M. Lynch and R.E. Harris, Minimal genetic findings and their cancer control implications: a family with the cancer family syndrome, JAMA 240 (1978), 535-538.

[122] R.M. Fusaro, H.T. Lynch, J. Pester and P.M. Lynch, Torre's syndrome as phenotypic expression of cancer family syndrome, Arch Dermatol 116 (1980), 986-987.

[123] H.T. Lynch, T.J. Drouhard, G.S. Schuelke, K.A. Biscone, J.F. Lynch and B.S. Danes, Hereditary nonpolyposis colorectal cancer in a Navajo Indian family, Cancer Genet Cytogenet 15 (1985), 209-213.

[124] P.M. Lynch, M.J. Wargovich, H.T. Lynch, C. Palmer, S. Lanspa and T. Drouhard et al., A follow-up study of colonic epithelial proliferation as a biomarker in a Native-American family with hereditary nonpolyposis colorectal cancer, $J$ Natl Cancer Inst 83 (1991), 951-954.

[125] H.T. Lynch, T. Drouhard, S.J. Lanspa, P. Lynch, E. Bronson and J.F. Lynch, Lynch syndrome II in a Navajo family: a revisit, American Indian Culture and Research Journal 16 (1992), 1-13.

[126] M. Nystrom-Lahti, R. Parsons, P. Sistonen, L. Pylkkanen, L.A. Aaltonen and F.S. Leach et al., Mismatch repair genes on chromosomes $2 p$ and $3 p$ account for a major share of 
hereditary nonpolyposis colorectal cancer families evaluable by linkage, Am J Hum Genet 55 (1994), 659-665.

[127] C.R. Boland and F.J. Troncale, Familial colonic cancer without antecedent polyposis, Ann Intern Med 100 (1984), 700701.

[128] M.A. Tempero, M.M. Jacobs, H.T. Lynch, C.L. Graham and A.J. Blotcky, Serum and hair selenium levels in hereditary nonpolyposis colorectal cancer, Biological Trace Element Research 6 (1984), 51-55.

[129] H.F.A. Vasen, P. Watson, J-P. Mecklin, P.M. Khan and H.T. Lynch, The International Collaborative Group on HNPCC, Anticancer Res 14 (1994), 1661-1664.

[130] H.T. Lynch, J.N. Marcus, P. Watson and J. Lynch, Familial breast cancer, cancer family syndromes, and predisposition to breast neoplasms, in: The Breast, K. Bland and E.M. Copeland, eds, Philadelphia: W.B.Saunders Co., 1991, pp. 262-291.

[131] C.R. Boland, T.F. Chen, S.J. Rinderle, J.H. Resau, G.D. Luk and H.T. Lynch et al., Use of the lectin from Amaranthus caudatus as a histochemical probe of proliferating colonic epithelial cells [published erratum appears in, Cancer Res 15:52(14) (July 1992), 4066, Cancer Res 51 (1991), 657665.

[132] C.R. Boland, M.A. Martin and I.J. Goldstein, Lectin reactivities as intermediate biomarkers in premalignant colorectal epithelium, J Cell Biochem Suppl 16G (1992), 103-109.

[133] G. Marra and C.R. Boland, Hereditary nonpolyposis colorectal cancer: the syndrome, the genes, and historical perspectives, J Natl Cancer Inst 87 (1995), 1114-1125.
[134] M.T. Hawn, A. Umar, J.M. Carethers, G. Marra, T.A. Kunkel and C.R. Boland et al., Evidence for a connection between the mismatch repair system and the G2 cell cycle checkpoint, Cancer Res 55 (1995), 3721-3725.

[135] C.R. Boland, Roles of the DNA mismatch repair genes in colorectal tumorigenesis, Int J Cancer 69 (1996), 47-49.

[136] Y. Akiyama, H. Sato, T. Yamada, H. Nagasaki, A. Tsuchiya and R. Abe et al., Germ-line mutation of the hMSH6/GTBP gene in an atypical hereditary nonpolyposis colorectal cancer kindred, Cancer Res 57 (1997), 3920-3923.

[137] C.R. Boland, S.N. Thibodeau, S.R. Hamilton, D. Sidransky, J.R. Eshleman and R.W. Burt et al., A National Cancer Institute workshop on microsatellite instability for cancer detection and familial predisposition: development of international criteria for the determination of microsatellite instability in colorectal cancer, Cancer Res 58 (1998), 5248-5257.

[138] M.A. Rodriguez-Bigas, H.F.A. Vasen, H.T. Lynch, P. Watson, T. Myrhøj, H.J. Järvinen et al., Characteristics of small bowel carcinoma in hereditary nonpolyposis colorectal carcinoma, Cancer 83 (1998), 240-244.

[139] S.C. Huang, J.E. Lavine, P.S. Boland, R.O. Newbury, R. Kolodner and T.T. Pham et al., Germline characterization of early-aged onset of hereditary non-polyposis colorectal cancer, J Pediatr 138 (2001), 629-635.

[140] D.K. Chang, A. Goel, L. Ricciardiello, D.H. Lee, C.L. Chang and J.M. Carethers et al., Effect of $\mathrm{H}(2) \mathrm{O}(2)$ on cell cycle and survival in DNA mismatch repair-deficient and -proficient cell lines, Cancer Lett 195 (2003), 243-251. 


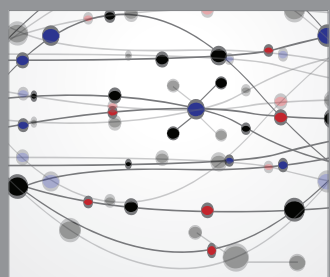

The Scientific World Journal
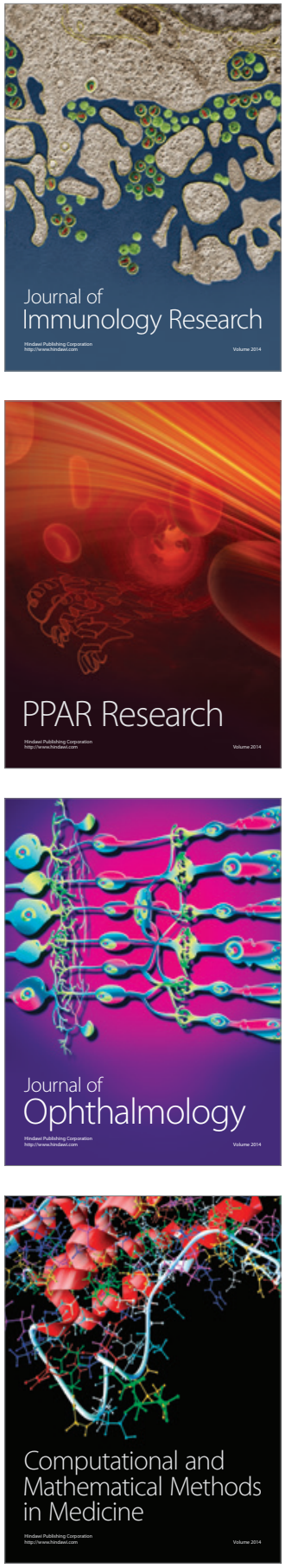

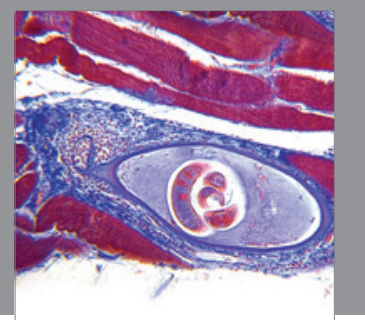

Gastroenterology

Research and Practice
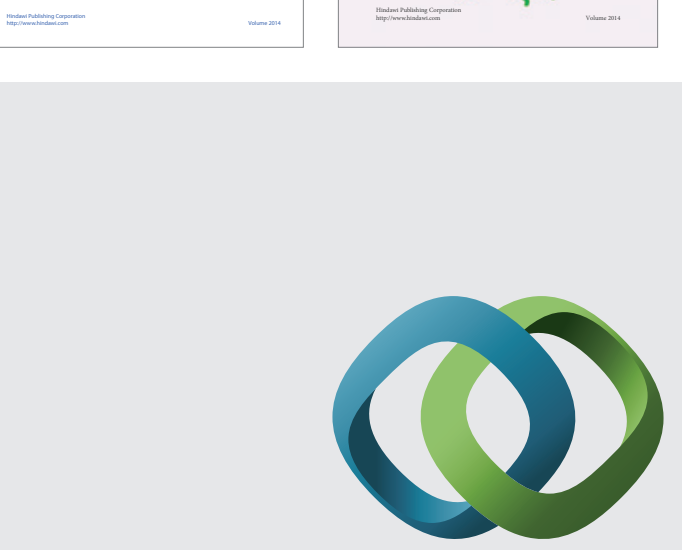

\section{Hindawi}

Submit your manuscripts at

http://www.hindawi.com
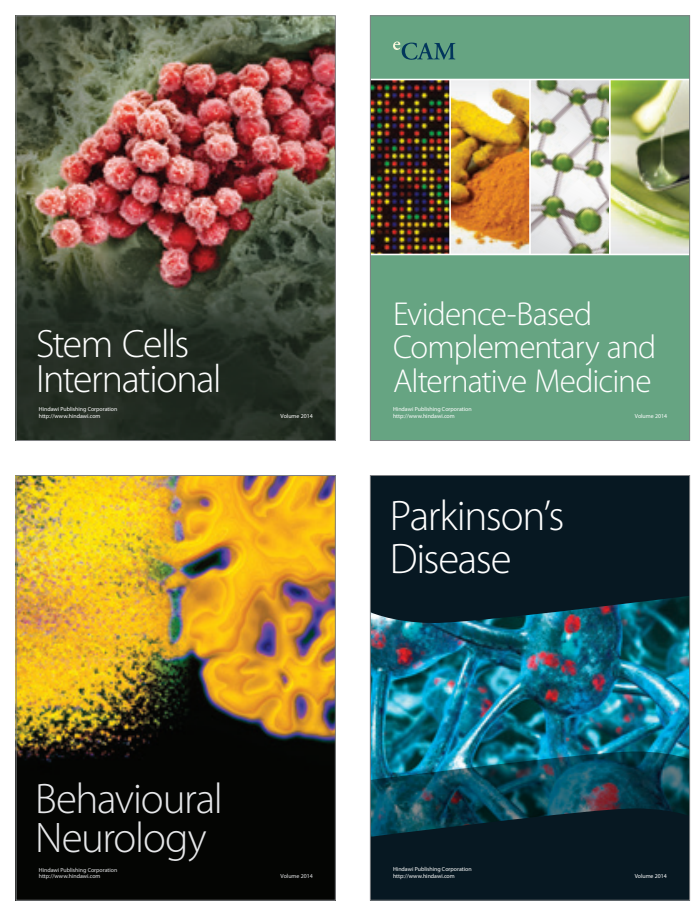

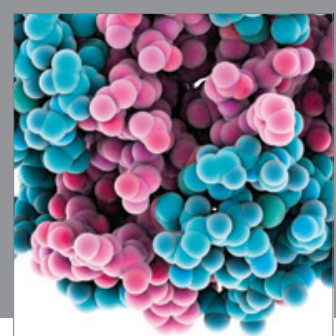

Journal of
Diabetes Research

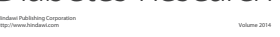

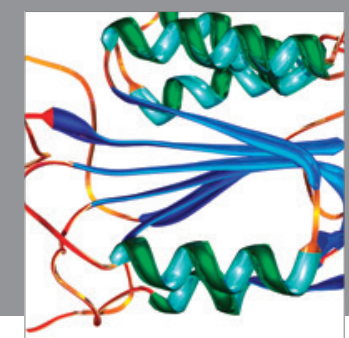

Disease Markers
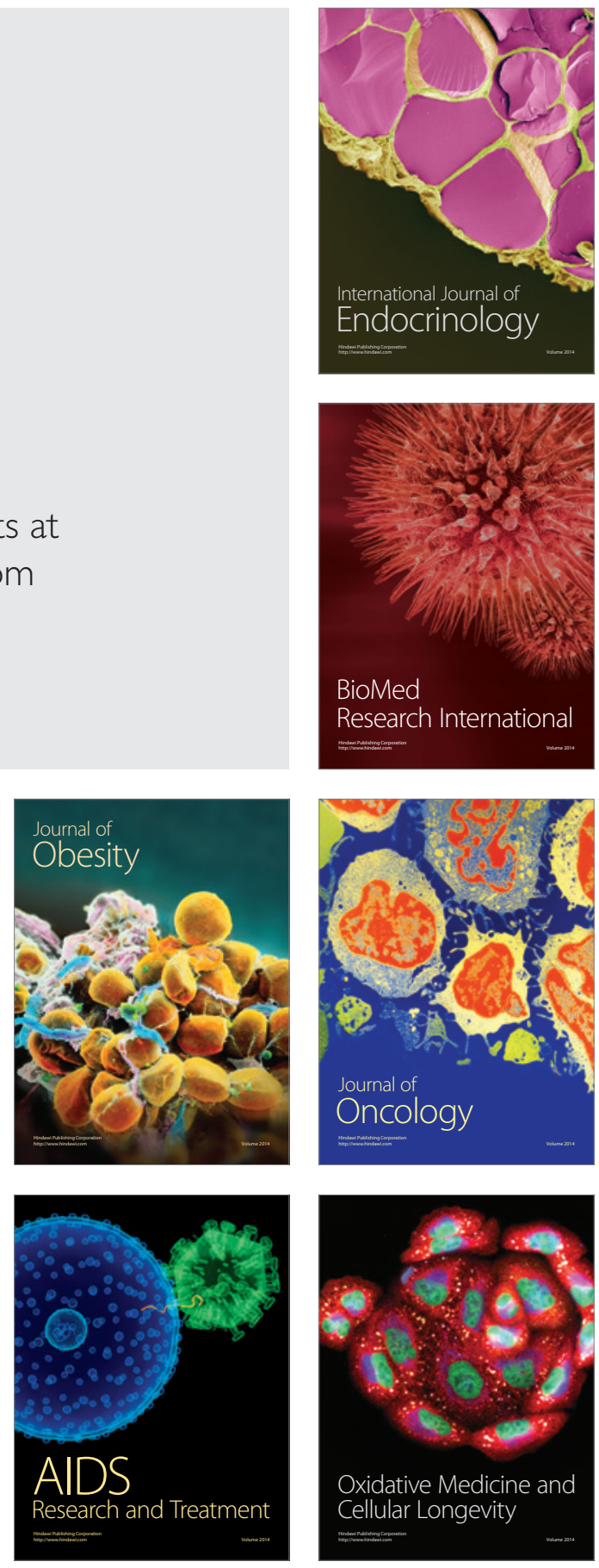